\title{
Mass Spectrometric Studies of the Gas Phase Retro-Michael Type Fragmentation Reactions of 2-Hydroxybenzyl- $N$-Pyrimidinylamine Derivatives
}

\author{
Hao-Yang Wang, Xiang Zhang, and Yin-Long Guo \\ Shanghai Mass Spectrometry Center, Shanghai Institute of Organic Chemistry, Chinese Academy of Sciences, \\ Shanghai, People's Republic of China

\section{Long $\mathrm{Lu}$} \\ Key Laboratory of Organofluorine Chemistry, Shanghai Institute of Organic Chemistry, Chinese Academy of \\ Sciences, Shanghai, People's Republic of China
}

The gas-phase fragmentation reactions of 2-hydroxybenzyl- $N$-pyrimidinylamine derivatives (Compounds 1 to 6 ), the O-N-type acid-catalyzed Smiles rearrangement products of 2-pyrimidinyloxy- $N$-arylbenzylamine derivatives, have been examined via positive ion matrix-assisted laser desorption/ionization (MALDI) infrared multiphoton dissociation (IRMPD) mass spectrometry in FT-ICR MS and via negative ion electrospray ionization (ESI) in-source collisioninduced dissociation (CID) mass spectrometry, respectively. The major fragmentation pathway of protonated 1 to 6 gives the $F$ ions under IRMPD; theoretical results show that the retro-Michael reaction channel is more favorable in both thermodynamics and kinetics. This explanation is supported by H/D exchange experiments and the MS/MS experiment of acetylated 1. Deprotonated 1 to 6 give rise to the solitary $E$ ions (aromatic nitrogen anions) in the negative ion in-source CID; theoretical calculations show that a retro-Michael mechanism is more reasonable than a gas-phase intramolecular nucleophilic displacement $\left(S_{N} 2\right)$ mechanism to explain this reaction process. (J Am Soc Mass Spectrom 2005, 16, 1561-1573) (C) 2005 American Society for Mass Spectrometry

$\mathrm{T}$ landem mass spectrometry of either positive or negative ions not only provides extensive structural information for organic molecules [1, 2], especially for peptides and proteins [3-5], but can also act as an important gas-phase "physical organic" tool for mechanistic studies of organic chemistry [6-8]. The solvent-free and unimolecular conditions in MS/MS make the gas-phase reactions different from the condensed phase analogous reactions; specifically, the gasphase chemistry may provide insight into some unique and intrinsic characteristics for the intramolecular organic reactions [9-13]. Previous IRMPD mass spectrometric studies of protonated 2-pyrimidinyloxy- $N$-arylbenzyl amine derivatives reveal some gas-phase rearrangement reactions [14]. In particular, the gasphase $S_{N}$ Ar type rearrangement inspired us to investigate the rearrangement reaction of 2-pyrimidinyloxy- $N$ arylbenzylamine derivatives in the condensed phase. The results show that the gas-phase $S_{N} A r$ type rearrangement has solution phase analogs, the acid-catalyzed Smiles rearrangement reaction, which is summa-

Published online July 11, 2005

Address reprint requests to Dr. Y.-L. Guo, Shanghai Mass Spectrometry Center, Shanghai Institute of Organic Chemistry, Chinese Academy of Sciences, Shanghai 200032, China. E-mail: ylguo@mail.sioc.ac.cn rized in Scheme 1. Six 2-hydroxybenzyl-Npyrimidinylamine derivatives (Compounds 1 to 6 ), the Smiles rearrangement products of 2-pyrimidinyloxy- $\mathrm{N}$ arylbenzylamine derivatives, are shown in Scheme 2.

As an important chemical pathway of this kind of herbicide, a thorough understanding of the MS/MS and $\mathrm{MS}^{\mathrm{n}}$ data of these rearrangement products is important for bioactivity mechanisms, degradation pathways, and metabolism research. Analysis of the positive ion MALDI-IRMPD data from protonated 1 to 6 reveals that the $F$ ions are main product ions. Two different mechanisms, an $S_{N} 2$ or a retro-Michael reaction, are proposed to explain the formation pathway of $F$ ions observed from positive ion MALDI-IRMPD of protonated 1 to 6 . Theoretical calculations show that the retro-Michael mechanism is more reasonable.

Compounds 1 to 6 have active phenol hydroxyl groups; we have also examined the fragmentation reactions under negative ion ESI in-source CID. Unusual aromatic nitrogen anions, $E$ ions from deprotonated 1 to 6 , are observed. Theoretical calculations also show that the retro-Michael mechanism is reasonable to explain the formation pathway of $E$ ions. Based on these results, the fragmentation reactions of 1 to 6 in either positive ion mode or negative ion mode can be generalized to a retro-Michael reaction initialized by the ortho-phenol 

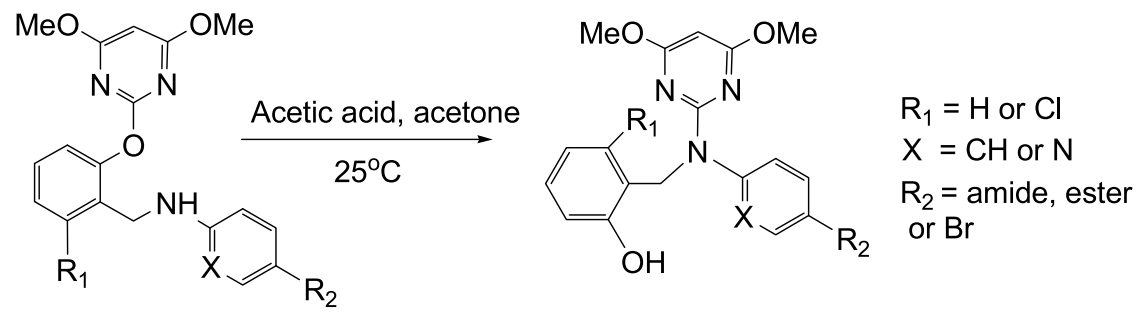

\title{
2-pyrimidinyloxy- $N$-arylbenzylamine 2-hydroxybenzyl- $N$-pyrimidinylamine
}

\begin{abstract}
Scheme 1. The 2-pyrimidinyloxy- $N$-arylbenzylamine derivatives rearrange to 2-hydroxybenzyl- $N$ pyrimidinylamine derivatives by an acid-catalyzed Smiles rearrangement mechanism at roomtemperature under acidic conditions.
\end{abstract}

hydroxyl group. Tandem mass spectrometric experiments of acetylated 1 were combined with the H/D exchange experiment to support the retro-Michael reaction mechanism.

\section{Experimental}

\section{Chemicals and Materials}

The structures of compounds ( 1 to 6 ) were verified by NMR, IR and MS after purification. MALDI matrix, DHB, was purchased from Sigma (Sigma-Aldrich Co., St. Louis, MO). Deuterated methanol ( $\left.>99 \%, \mathrm{CD}_{3} \mathrm{OD}\right)$ was obtained from Cambridge Isotopes Laboratory (Andover, MA).

\section{Acetylation of Compound 1}

Acetylation of Compound 1 was performed by dissolving $110 \mathrm{mg}$ of Compound $1 \mathrm{in} 5 \mathrm{~mL}$ acetone solution and reacting with excess acetic anhydride and triethylamine. The collected acetylated Compound 1 was obtained by removing the solvent residue under vacuum conditions. NMR and IR verified the structure of the acetylated Compound 1.

\section{H/D Exchange Experiment for Compound 1}

$\mathrm{H} / \mathrm{D}$ exchange was achieved by dissolving Compound 1 in $\mathrm{CD}_{3} \mathrm{OD}$ to support the ion-neutral complex intermediate process in the formation pathways of the $F$ ion at $\mathrm{m} / \mathrm{z} 318$ from protonated 1. Sample solutions were infused into the electrospray interface using a ColeParmer syringe pump (Cole-Parmer Instruments, Vernon Hills, IL) at a flow rate of $10 \mu \mathrm{L} / \mathrm{min}$. Fully H/D exchanged ion species $[M(D)+D]^{+},[M(D)+N a]^{+}$and the corresponding product ions were observed and recorded by a quadrupole MS (Agilent Technologies, Palo Alto, CA) with in-source CID in positive ion mode.

\section{MALDI-IRMPD Analysis}

The experiments were performed on a FT-ICR mass spectrometer (Ionspec, Irvine, CA) equipped with a 4.7 $\mathrm{T}$ actively shielded super-conducting electromagnet<smiles>CCCOC(=O)c1ccc(N(Cc2ccccc2O)c2nc(OC)cc(OC)n2)cc1</smiles>

1 M.W. 423<smiles>CCN(CC)C(=O)c1ccc(N(Cc2c(O)cccc2Cl)c2nc(OC)cc(OC)n2)cc1</smiles>

4 M.W. 470<smiles>CCCOC(=O)c1ccc(N(Cc2c(O)cccc2Cl)c2nc(OC)cc(OC)n2)cc1</smiles>

2 M.W. 457<smiles>COc1cc(OC)nc(N(Cc2ccccc2O)c2ccc(Br)cc2)n1</smiles>

5 M.W. 416<smiles>COc1cc(OC)nc(N(Cc2ccccc2O)c2ccc(C(=O)N3CCCCC3)cc2)n1</smiles>

3 M.W. 448<smiles>COc1cc(OC)nc(N(Cc2c(O)cccc2Cl)c2ccc(Br)cc2)n1</smiles>

6 M.W. 450

Scheme 2. Chemical structures of 2-hydroxybenzyl- $N$-pyrimidinylamine derivatives (1 to 6, molecular weight in $\mathrm{Da})$. 

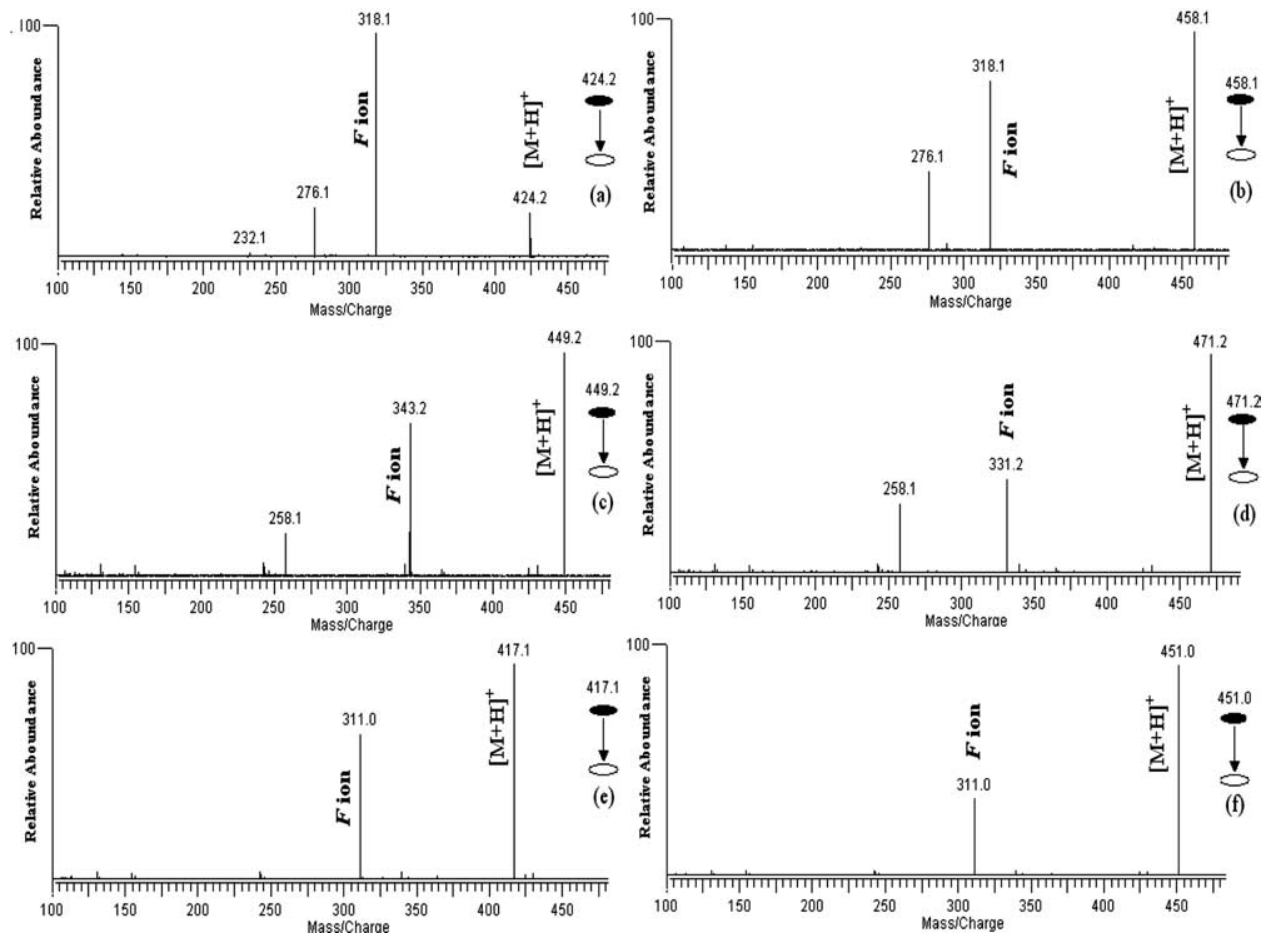

Figure 1. The IRMPD mass spectra of protonated 1 to 6 : (a) protonated 1 at $\mathrm{m} / \mathrm{z} 424$; (b) protonated 2 at $\mathrm{m} / \mathrm{z} 458$; (c) protonated 3 at $\mathrm{m} / \mathrm{z} 449$; (d) protonated 4 at $\mathrm{m} / \mathrm{z} 471$; (e); protonated 5 at $\mathrm{m} / \mathrm{z} 417$; (f) protonated 6 at $m / z 451$.

(Cryomagnetics, Oak Ridge, TN). The external Ionspec MALDI ion source used a ND:YAG laser (355 nm, New Wave, Fremont, CA). Ions were transferred via a quadrupole ion guide to the capacitively coupled closed cylindrical cell. Ions of interest were isolated using the arbitrary waveform generator. The arbitrary amplitude was set to $60 \mathrm{~V}(\mathrm{~b}-\mathrm{p})$ and the mass isolation window was set as $0.8 \mathrm{~m} / \mathrm{s}$ to eliminate the unwanted ions. IRMPD experiments were performed with a model SYNRAD series $48 \mathrm{CO}_{2}$ laser (75 MAX). The intensity of
IRMPD laser irradiation was varied between $\sim 50$ to $100 \%$ as needed at a flux of $75 \mathrm{~W} / \mathrm{cm}^{2}$. The IRMPD laser irradiation pulse time was set as $\sim 500$ to $1000 \mathrm{~ms}$ for protonated compounds to give sufficient energy and time for dissociation [14].

\section{ESI In-Source CID Analysis}

The ESI in-source CID experiments were performed with an Agilent LC/MSD-SL quadrupole mass spectrometer

Table 1. Comparison of the results of accurate mass determinations by FT-ICR MS and the actual masses for the proposed structures of the main product ions of protonated 1 to 6

\begin{tabular}{|c|c|c|c|c|}
\hline Compounds & Composition & Detected mass & Accurate mass & Relative error (ppm) \\
\hline \multirow[t]{4}{*}{1} & $\mathrm{C}_{23} \mathrm{H}_{26} \mathrm{~N}_{3} \mathrm{O}_{5}$ & 424.1881 & 424.1867 & 3.3 \\
\hline & $\mathrm{C}_{16} \mathrm{H}_{20} \mathrm{~N}_{3} \mathrm{O}_{4}$ & 318.1446 & 318.1448 & -0.6 \\
\hline & $\mathrm{C}_{13} \mathrm{H}_{14} \mathrm{~N}_{3} \mathrm{O}_{4}$ & 276.0978 & 276.0979 & -0.3 \\
\hline & $\mathrm{C}_{12} \mathrm{H}_{14} \mathrm{~N}_{3} \mathrm{O}_{2}$ & 232.1078 & 232.1081 & -1.1 \\
\hline \multirow[t]{3}{*}{2} & $\mathrm{C}_{23} \mathrm{H}_{25} \mathrm{~N}_{3} \mathrm{O}_{5} \mathrm{Cl}$ & 458.1466 & 458.1477 & -2.5 \\
\hline & $\mathrm{C}_{16} \mathrm{H}_{20} \mathrm{~N}_{3} \mathrm{O}_{4}$ & 318.1437 & 318.1448 & -3.5 \\
\hline & $\mathrm{C}_{13} \mathrm{H}_{14} \mathrm{~N}_{3} \mathrm{O}_{4}$ & 276.0968 & 276.0979 & -3.9 \\
\hline \multirow[t]{3}{*}{3} & $\mathrm{C}_{25} \mathrm{H}_{29} \mathrm{~N}_{4} \mathrm{O}_{4}$ & 449.2191 & 449.2183 & 1.7 \\
\hline & $\mathrm{C}_{18} \mathrm{H}_{23} \mathrm{~N}_{4} \mathrm{O}_{3}$ & 343.1773 & 343.1765 & 2.4 \\
\hline & $\mathrm{C}_{13} \mathrm{H}_{12} \mathrm{~N}_{3} \mathrm{O}_{3}$ & 258.0880 & 258.0873 & 2.6 \\
\hline \multirow[t]{3}{*}{4} & $\mathrm{C}_{24} \mathrm{H}_{28} \mathrm{~N}_{4} \mathrm{O}_{4} \mathrm{Cl}$ & 471.1799 & 471.1794 & 1.1 \\
\hline & $\mathrm{C}_{17} \mathrm{H}_{23} \mathrm{O}_{3} \mathrm{~N}_{4}$ & 331.1773 & 331.1765 & 2.5 \\
\hline & $\mathrm{C}_{13} \mathrm{H}_{12} \mathrm{~N}_{3} \mathrm{O}_{3}$ & 258.0881 & 258.0873 & 3.0 \\
\hline \multirow[t]{2}{*}{5} & $\mathrm{C}_{18} \mathrm{H}_{18} \mathrm{~N}_{4} \mathrm{O}_{3} \mathrm{Br}$ & 417.0566 & 417.0557 & 2.2 \\
\hline & $\mathrm{C}_{11} \mathrm{H}_{12} \mathrm{~N}_{4} \mathrm{O}_{2} \mathrm{Br}$ & 311.0146 & 311.0138 & 2.5 \\
\hline \multirow[t]{2}{*}{6} & $\mathrm{C}_{18} \mathrm{H}_{17} \mathrm{~N}_{4} \mathrm{O}_{3} \mathrm{BrCl}$ & 451.0177 & 451.0167 & 2.2 \\
\hline & $\mathrm{C}_{11} \mathrm{H}_{11} \mathrm{~N}_{4} \mathrm{O}_{2} \mathrm{Br}$ & 311.0148 & 311.0138 & 3.2 \\
\hline
\end{tabular}


<smiles>[R2]c1ccc([NH+](c2nc(OC)cc(OC)n2)C23COc4cccc([R7])c4C2(O)C3)cc1</smiles>

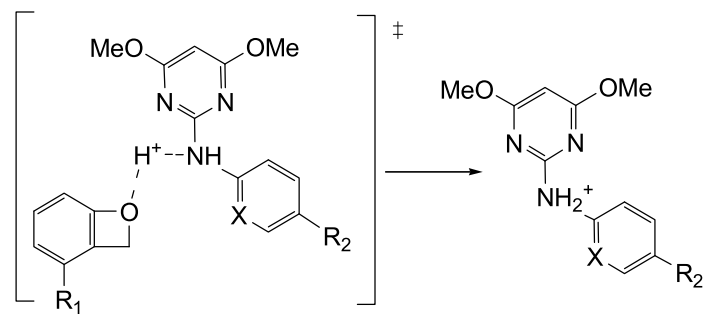

lon-neutral complex 1

INC 1<smiles>[R]c1ccc([NH+](CCCCC)c2nc(OC)cc(OC)n2)c([R2])c1</smiles>

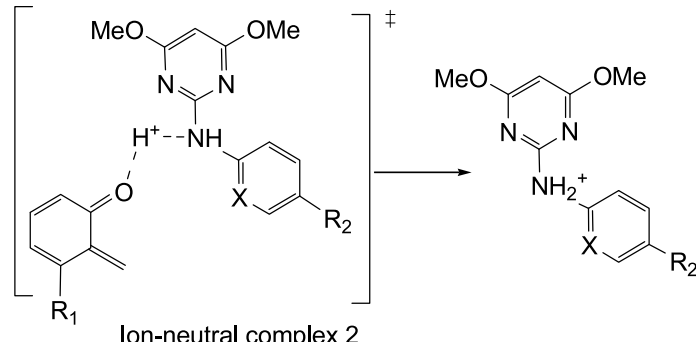

INC 2

Scheme 3. Two mechanisms are proposed to explain the formation of $F$ ions observed in IRMPD from protonated 1 to 6 . Path $A$ is proposed to be a gas-phase intramolecular $S_{N} 2$ reaction mechanism. Path $\mathbf{B}$ is proposed to be a gas-phase retro-Michael reaction mechanism.

(Agilent Technologies). The capillary voltage was set to $-3600 \mathrm{~V}$ for positive ion mode and $+4000 \mathrm{~V}$ for negative ion mode. The nebulizing gas flow rate and curtain gas pressure were $10 \mathrm{ml} \mathrm{min} \mathrm{m}^{-1}$ and $35 \mathrm{psi}$, respectively. The fragmentation voltage was varied from 150 to $250 \mathrm{~V}$ to give suitable energy for dissociation.
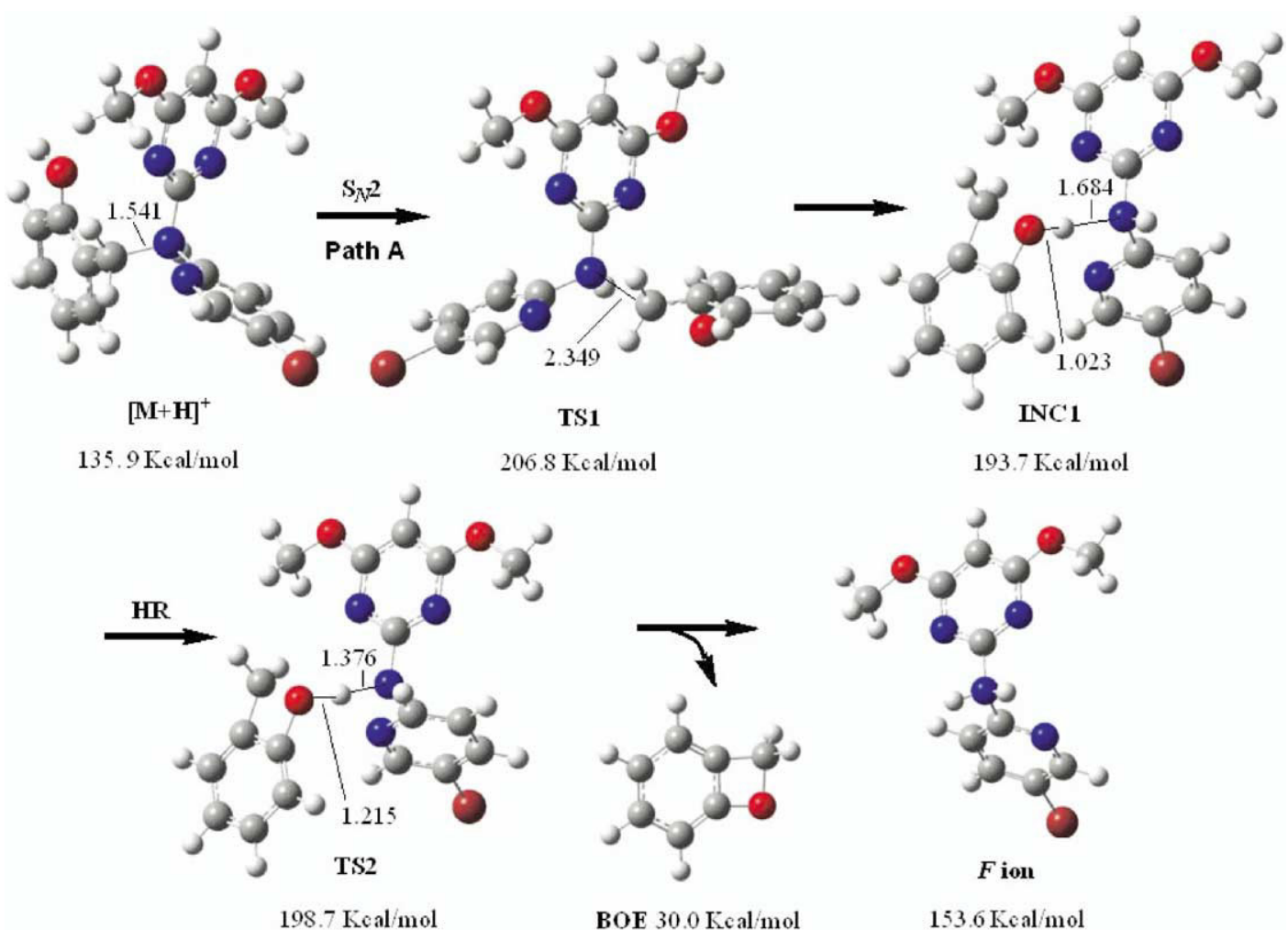

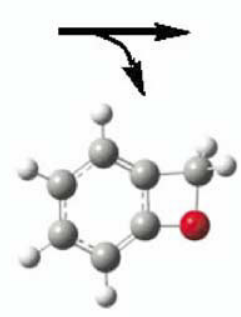

BOE $30.0 \mathrm{Keal} / \mathrm{mol}$

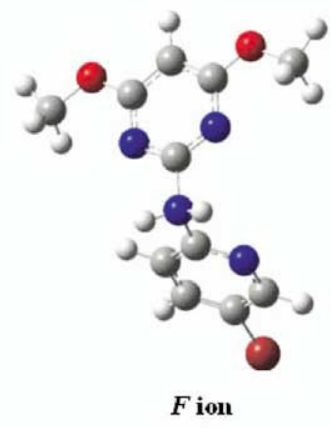

$153.6 \mathrm{Keal} / \mathrm{mol}$

Figure 2. PM3 optimized structures of the species in the $\mathrm{S}_{N} 2$ reaction path of $[5+\mathrm{H}]^{+}$via transition-state (TS1) and the proton transfer reaction within the ion-neutral complex 1 (INC1) via transition-state 2 (TS2). Heats of formation are given in $\mathrm{kcal} / \mathrm{mol}$ and the lengths of the chemical bonds are given in $\AA$. 


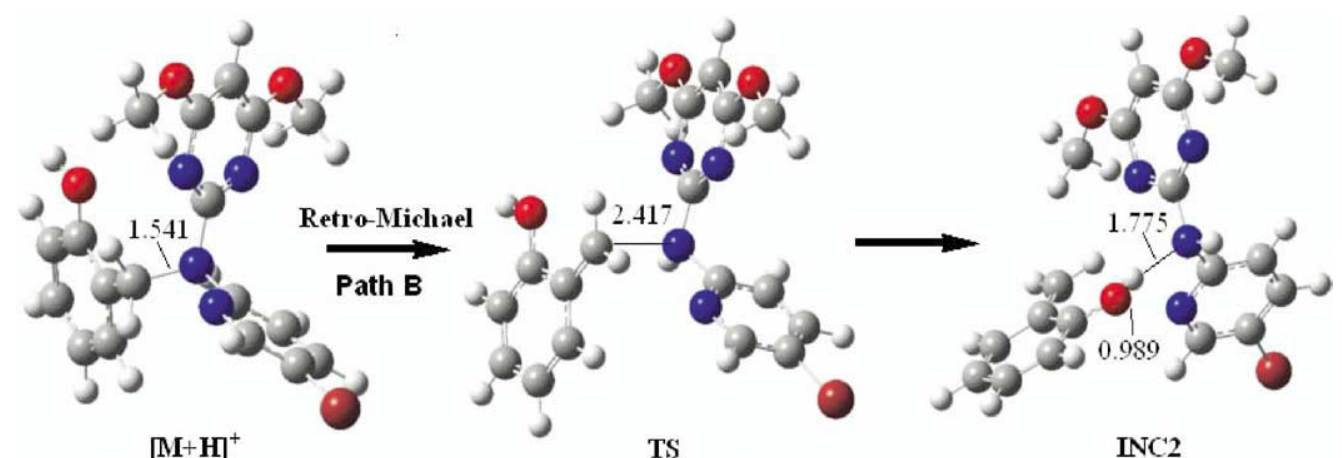

$135.9 \mathrm{Keal} / \mathrm{mol}$

$167.3 \mathrm{Kcal} / \mathrm{mol}$

$159.3 \mathrm{Kcal} / \mathrm{mol}$

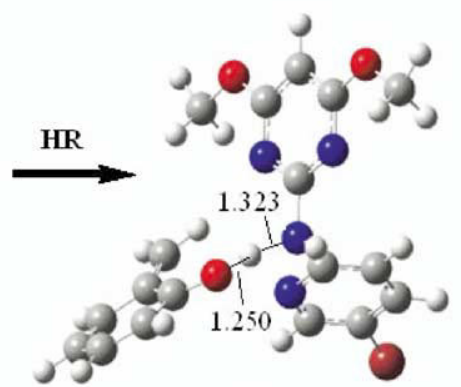

TS

$1714 \mathrm{Kcal} / \mathrm{mol}$

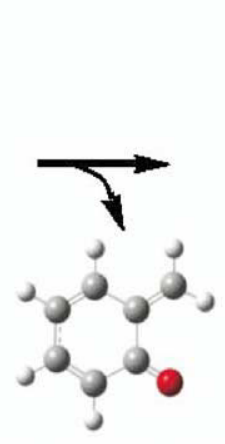

ME C $11.7 \mathrm{Kcal} / \mathrm{mol}$

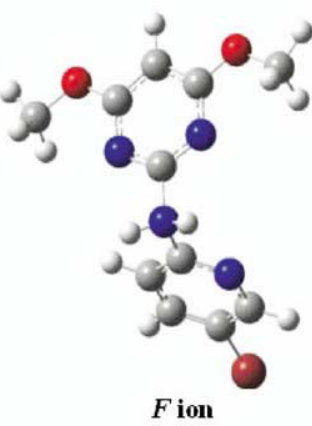

$153.6 \mathrm{Kcal} / \mathrm{mol}$

Figure 3. PM3 optimized structures of the species in the retro-Michael reaction path of $[5+\mathrm{H}]^{+}$via transition-state (TS3) and the proton transfer reaction within the ion-neutral complex 2 (INC2) via transition-state 4 (TS4). Heats of formation are given in $\mathrm{kcal} / \mathrm{mol}$ and the lengths of the chemical bonds are given in $\AA$.

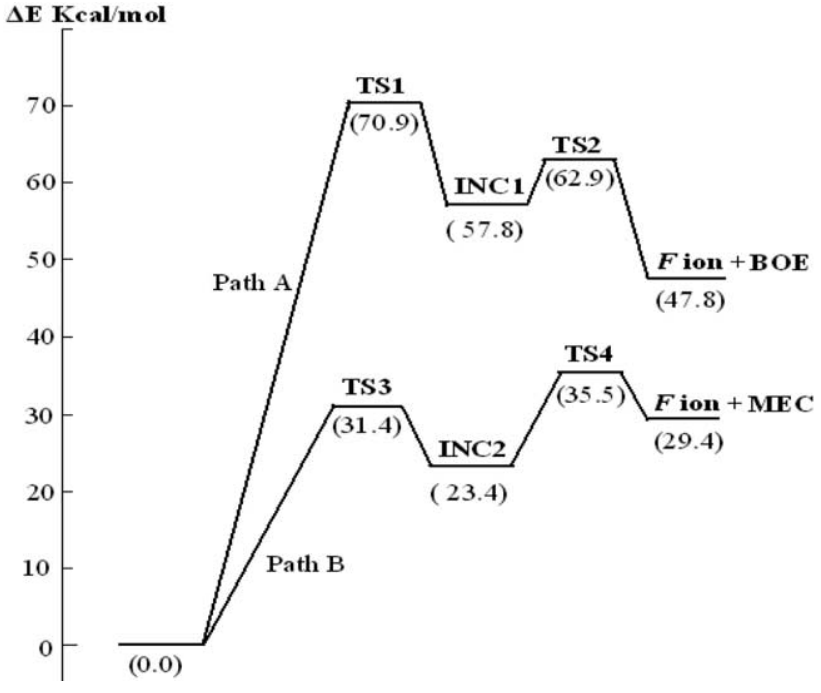

Figure 4. Schematic potential energy surface (relative energies are given in $\mathrm{kcal} / \mathrm{mol}$ ) for the two proposed fragmentation pathways of $[5+\mathrm{H}]^{+}$, calculated by semiempirical PM3. Path $\mathrm{C}$ is an intramolecular $\mathrm{S}_{N} 2$ reaction channel via TS1 to INC1, then the $F$ ion is formed via proton transfer in INC1 through TS2; path D is a retro-Michael reaction channel via TS3 to INC2, then the $F$ ion is formed via proton transfer in INC1 through TS4.

\section{Computational Methods}

All theoretical calculations were carried out by the semiempirical PM3 method with Spartan molecular

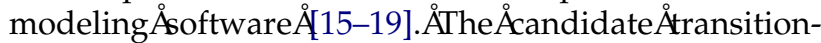
state structures and key structures on the potential energy surface were optimized. Heats of formation (in $\mathrm{kcal} / \mathrm{mol}$ ) of the optimized structures were calculated [16 ̊̊18].ÅAllÅoptimized Åstructures ÅwereÅsubjected Åto vibrational frequency analysis. The semiempirical PM3 optimized structures were shown by Gauss View (3.07)

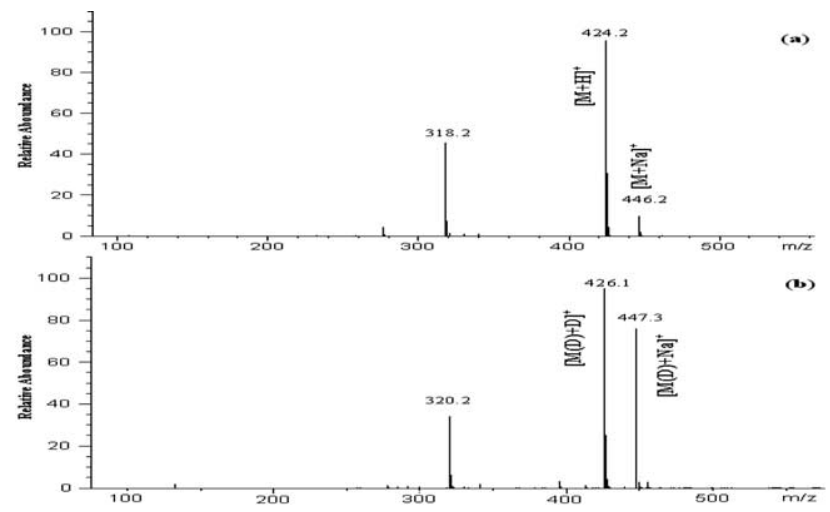

Figure 5. The positive ion ESI in-source CID mass spectra of 1 $(\mathrm{MW}=423$ ) and fully deuterated 1 : (a) protonated 1 at $\mathrm{m} / \mathrm{z} 424$; (b) fully deuterated 1 at $\mathrm{m} / \mathrm{z} 426$. 


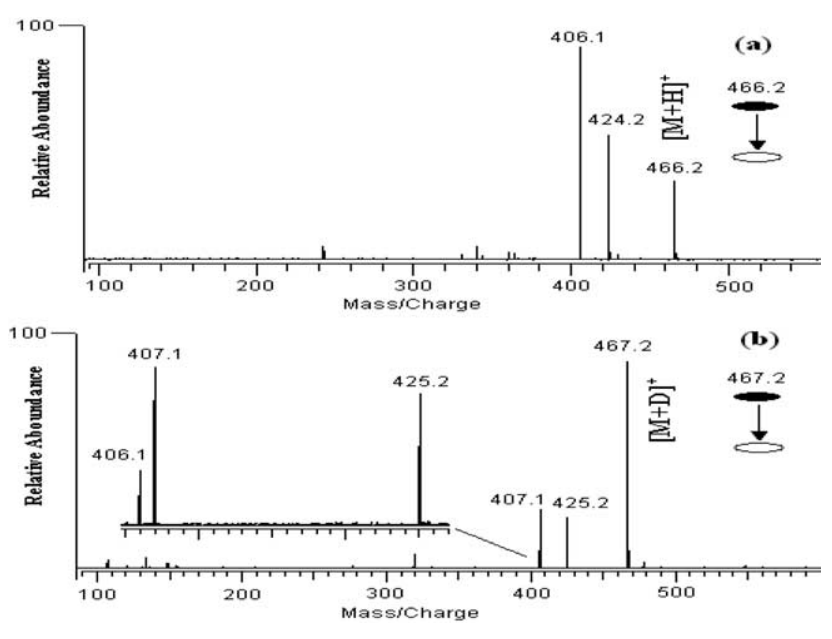

Figure 6. The MS/MS spectrum of protonated acetylated 1 and deuterated acetylated 1: (a) protonated acetylated 1 at $\mathrm{m} / \mathrm{z} 466$; (b) deuterated acetylated 1 at $\mathrm{m} / \mathrm{z} 467$.

software to give higher quality images of these structures.

\section{Results and Discussion}

\section{MALDI IRMPD Studies of the Fragmentation Reactions of Protonated 1 to 6}

IRMPD is a general method for activating ions trapped in a FT-ICR cell to generate fragment ions and is widely used for structural analysis and gas-phase chemistry

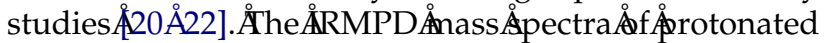
1 to 6 obtained using Ionspec FT-ICR MS are depicted in

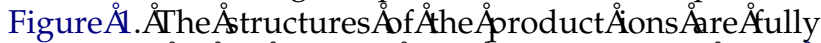

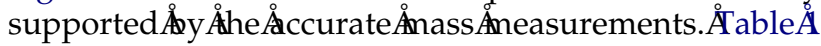
shows a comparison of the masses determined and the actual masses of the proposed structures, and the corresponding element compositions of the main fragment ions. The relative errors are all less than $5 \mathrm{ppm}$, so the results indicate that the proposed structures have the only reasonable elemental compositions. According to the IRMPD data, the major dissociation pathway for protonated 1 to 6 is to form the $F$ ions and two different pathways are proposed to explain the formation of $F$ ions, which is shown in Scheme 3.

\section{Modeling the Formation Process of F Ions}

The goal of calculations was to show the possible existence of some transition states and intermediates involved in the two different pathways. Path $\mathbf{A}$ is proposed to be a gas-phase intramolecular $S_{N} 2$ reaction mechanism. Path $\mathbf{B}$ is proposed to be a gas-phase retro-Michael reaction mechanism. Because the $F$ ion at $\mathrm{m} / \mathrm{z} 311$ is the only product ion of protonated 5 , it is selected as the model to illustrate the formation of the $F$ ion at $m / z$ 311. The structures of the key species on the potential energy surface of protonated 5 were optimized by the semiempirical PM3 method.

Gas-phase $S_{N} 2$ reactions are widely used to explain neutral loss processes in MS/MS. O'Hair and coworkers have proposed gas-phase neighboring group effects in the side-chain losses from protonated serine [23-26].Ån $\AA$ Path ÅA, Åthe Åphenol Åhydroxyl Ågroup Áfirst attacks the benzylic carbon, inducing cleavage of the $\mathrm{C}-\mathrm{N}$ bond to form an ion-neutral complex 1 (INC1) through transition-state 1 (TS1). In INC1, protonated $2 \mathrm{H}$-benzo[b]oxete (BOE) bonds with the neutral pyrimidinylamine by hydrogen bonding, then the proton transfers from protonated $\mathrm{BOE}$ to pyrimidinylamine to form the $F$ ion at $\mathrm{m} / \mathrm{z} 311$ via transition-state 2 (TS2). It was not possible to fully converge with the structure of TS1. The energy of TS1 was obtained as the maximum for a set of partial geometry optimiza-

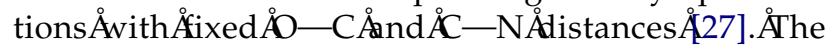
structure of TS2 was optimized by semiempirical PM3 without imposing any constraints. The semiempirical PM3 optimized structures, the lengths of important chemical bonds (in $\AA$ ), and the calculated heats of formation of species involved in this intramolecular $\mathrm{S}_{N} 2$ Aeaction $\mathrm{Are}$ Åeported Ån $\mathrm{Figure} \AA$.

The retro-Michael cleavage reaction was reported as an important dissociation pathway of $\beta$-amino acid/esters hond Åelated đendrimer polymers $28 \AA 31$ ] Path $\mathbf{B}$ represents a gas-phase retro-Michael reaction. In this process, the rearrangement of lone pair electrons of phenol hydroxyl directly induces the cleavage of the $\mathrm{C}-\mathrm{N}$ bond and the formation of an ion-neutral complex 2 (INC2) through transition-state 3 (TS3). In INC2, protonated 6-methylenecyclohexa2,4-dienone (MCE) connects with the neutral pyrimidinylamine by hydrogen bonding. Then the proton transfers from protonated MCE to pyrimidinylamine to form the $F$ ion at $\mathrm{m} / \mathrm{z} 311$ via transition-state 4 (TS4). The structures of TS3 and TS4 were full optimized by semiempirical PM3 without imposing any constraints. The semiempirical PM3 optimized structures, the lengths of important chemical bonds (in $\AA$ ), and the calculated heats of formation of species involved in this retro-Michael reaction are reported in Figure $\$$.

Table 2. Comparison of the results of accurate mass determinations by FT-ICR MS and the actual masses for the proposed structures of the main product ions of protonated acetylated 1

\begin{tabular}{lcccr}
\hline Compounds & Composition & Detected mass & Accurate mass & Relative error (ppm) \\
\hline \hline Acetylated 1 & $\mathrm{C}_{25} \mathrm{H}_{28} \mathrm{~N}_{3} \mathrm{O}_{6}$ & 466.1966 & 466.1973 & -1.5 \\
& $\mathrm{C}_{23} \mathrm{H}_{26} \mathrm{~N}_{3} \mathrm{O}_{5}$ & 424.1860 & 424.1867 & -1.7 \\
& $\mathrm{C}_{22} \mathrm{H}_{20} \mathrm{~N}_{3} \mathrm{O}_{5}$ & 406.1390 & 406.1398 & -2.0 \\
\hline
\end{tabular}




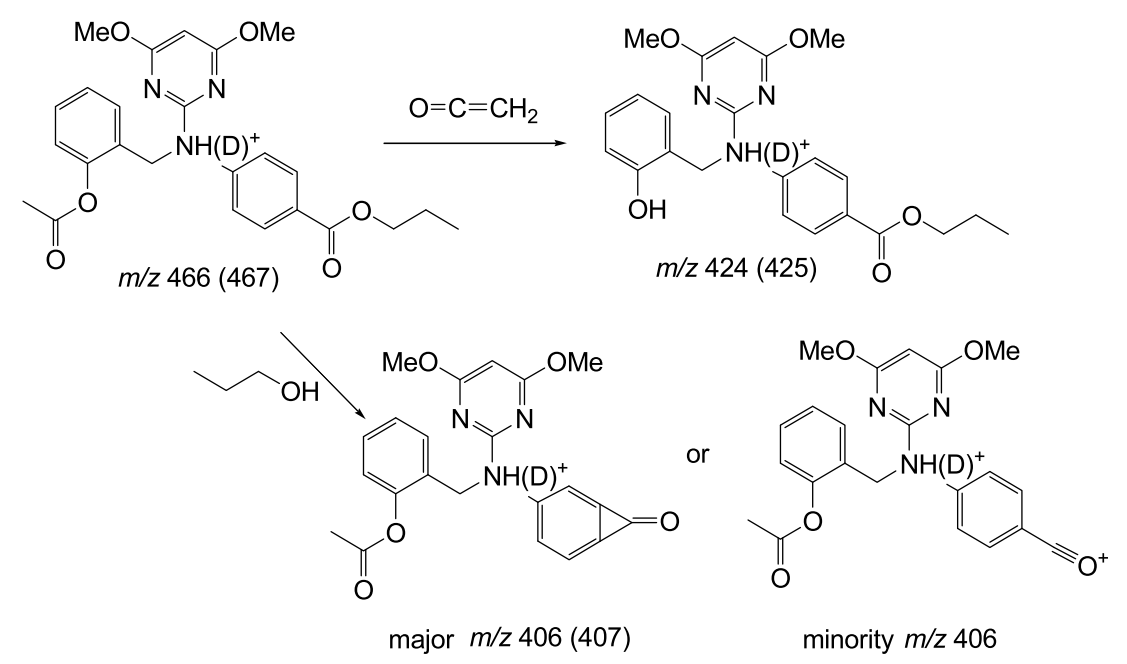

Scheme 4. The proposed dissociation pathways of protonated acetylated 1 . The data in parentheses are those observed in MS/MS of deuterated acetylated 1.

A schematic potential energy surface for the two proposed Åmechanisms Ås Ågiven $\AA$ in Figure $\AA$. Annalysis of $\AA$ Figure $\AA$ Åhows Åhat Åhe reaction path via TS1 $(70.9 \mathrm{kcal} / \mathrm{mol})$ is much higher than that for the retro-Michael path via TS3 (31.4 $\mathrm{kcal} / \mathrm{mol})$. Moreover, the heat of formation of MCE $(11.7 \mathrm{kcal} / \mathrm{mol})$ is much lower than that of BOE $(30.0$ $\mathrm{kcal} / \mathrm{mol}$ ); therefore, the product energy of the retroMichael reaction is much lower than that of the $\mathrm{S}_{N} 2$ reaction. These results indicate that the retro-Michael mechanism is more favorable than the $\mathrm{S}_{N} 2$ mechanism in both thermodynamics and kinetics.

From the changes in the $\mathrm{O}-\mathrm{H}$ and $\mathrm{N}-\mathrm{H}$ bond lengths of TS4, the dynamic process of the proton migration in INC2 can be viewed clearly. The proton of protonated MCE in the ion-neutral complex is captured by pyrimidinylamine because of its much higher proton affinity than that of ketone. Besides the calculations, additional experiments were performed to test the formation mechanism of $F$ ions: (1) H/D

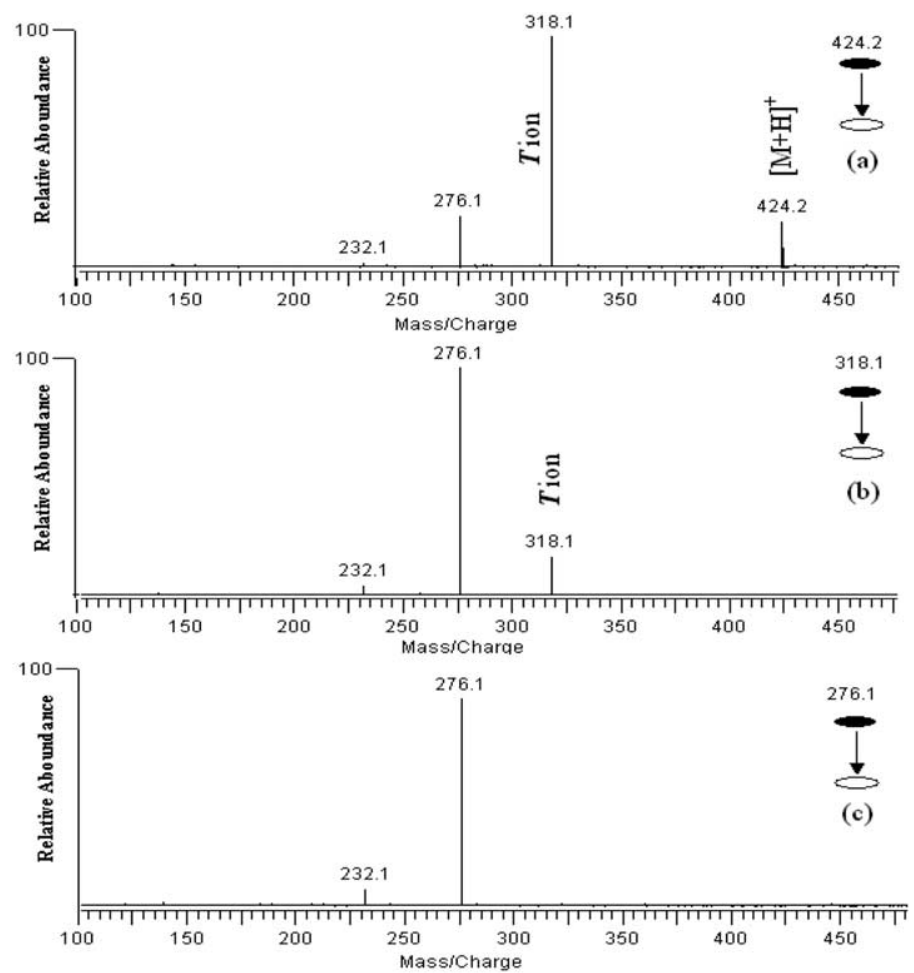

Figure 7. The IRMPD mass spectra of protonated 1, the ion at $\mathrm{m} / \mathrm{z} 318$ and the ion at $\mathrm{m} / \mathrm{z} 276$ : (a) protonated 1 at $\mathrm{m} / \mathrm{z} 424$; (b) the ion at $\mathrm{m} / \mathrm{z} 318$; (c) the ion at $\mathrm{m} / \mathrm{z} 276$. 

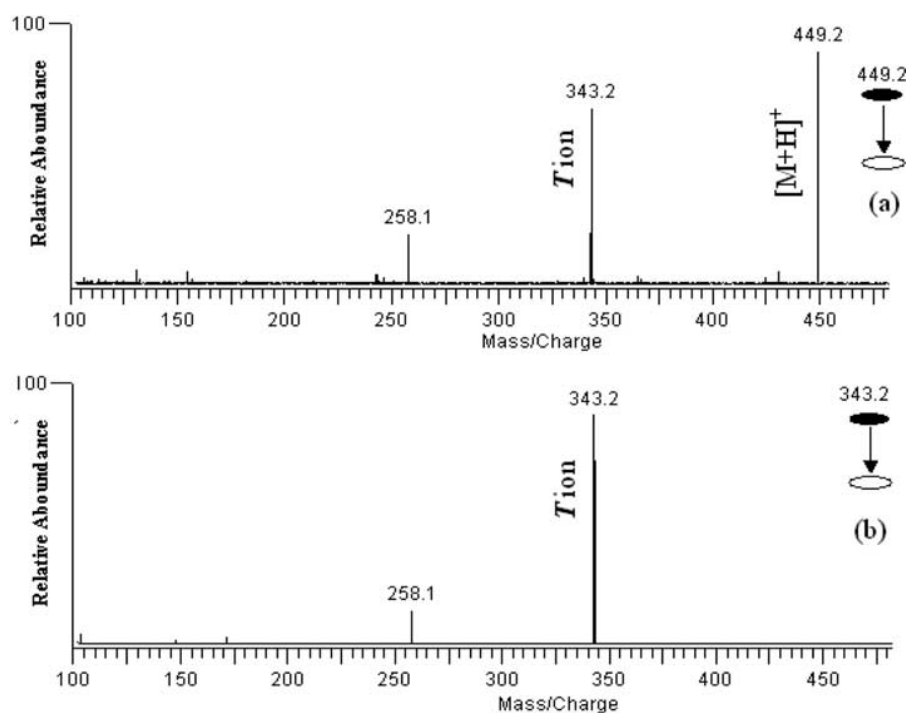

Figure 8. The IRMPD mass spectra of protonated 3 and the ion at $m / z$ 343: (a) protonated 3 at $m / z 449$; (b) the ion at $m / z 343$.

exchange experiments to test the mechanism involving ion-neutral complex intermediates. (2) acetylation of phenol hydroxyl group to test the retro-Michael reaction channel.

\section{Tracing the Proton Migration in the Ion-Neutral Complex via $H / D$ Exchange Experiments}

Ion-neutral complexes (INC) are widely reported inter-

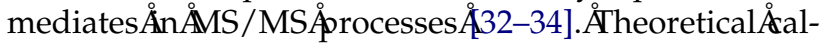
culations of the proton transfer process in INC2 via TS4 show that the proton on the pyrimidinylamine amine arises from the phenol hydroxyl. H/D exchange experiments were used to examine this process. This mechanism should result in the $F$ ion at $m / z 320$ from the fully deuterated Compound 1. The experiment was performed with a quadrupole mass spectrometer with an
ESI source by in-source CID. The positive ion ESI in-source CID mass spectra of protonated $1(\mathrm{MW}=423)$

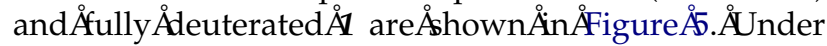
comparable collision conditions, the $[\mathrm{M}(\mathrm{D})+\mathrm{D}]^{+}$ion at $\mathrm{m} / \mathrm{z} 426$ from liquid phase H/D exchange decomposes almost exclusively to the $F$ ion at $\mathrm{m} / \mathrm{z} 320$. This result indicates that the proton of the phenol hydroxyl group transfers to the amine to form the $F$ ion. Thus the ion-neutral process was confirmed by determining the origin of the proton to form the $F$ ion with theoretical calculations and H/D exchange experiments.

\section{Probing the Retro-Michael Mechanism by Acetylation of Hydroxyl Group}

It is proposed that the first step of the formation of the $F$ ion at $m / z 311$ is a gas-phase retro-Michael mechanism.

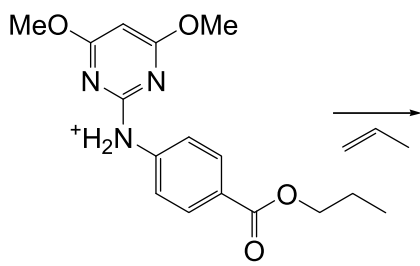

$m / z 318$<smiles>COc1cc(Nc2ccc(C(=O)O)cc2)nc(OC)n1</smiles>

$m / z 276$<smiles>COc1cc(OC)nc(Nc2ccccc2)n1</smiles>

$m / z 232$
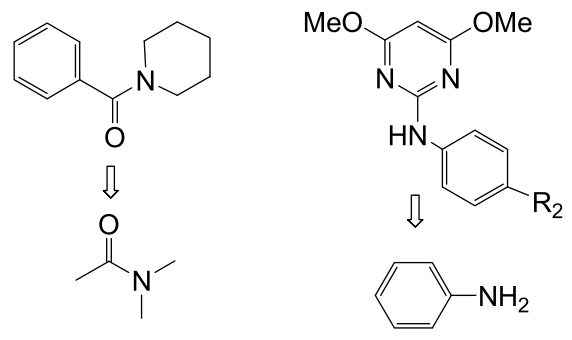

PA: $908 \mathrm{~kJ} / \mathrm{mol}$

PA: $921 \mathrm{~kJ} / \mathrm{mol}$

Scheme 5. Formation pathways of the ions at $m / z 276$ and 232 from the $F$ ion at $m / z 318$. 


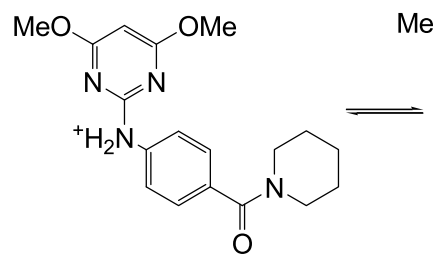

$m / z 343$<smiles>COc1cc(OC)nc(Nc2ccc(C(=O)[NH+]3CCCCC3)cc2)n1</smiles>

$\mathrm{MeO}$

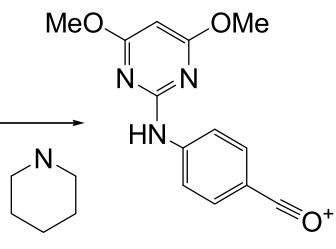

$m / z 258$

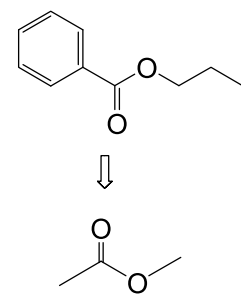

PA: $821 \mathrm{~kJ} / \mathrm{mol}$
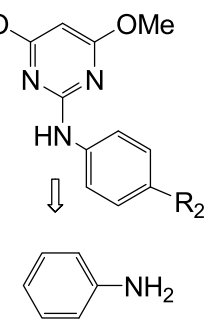

PA: $921 \mathrm{~kJ} / \mathrm{mol}$

Scheme 6. Formation pathway of the ion at $\mathrm{m} / \mathrm{z} 258$ from the $F$ ion at $\mathrm{m} / \mathrm{z} 343$.

This reaction is initiated by the rearrangement of lone pair electrons on the phenol hydroxyl group. A modification to the hydroxyl group that decreases the charge

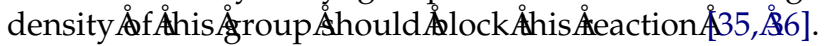
Acetylation of the phenol hydroxyl group of Compound 1 meets this criterion. The MS/MS spectrum of

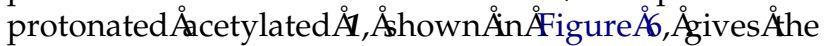
ion at $m / z 424$ by loss of propanol and the ion at $m / z 406$ by loss of $\mathrm{CH}_{2}=\mathrm{C}=\mathrm{O}$. The accurate mass determination

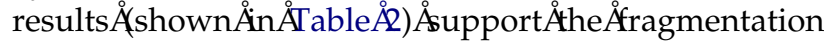
pathways. This fragmentation pathway is different than that of protonated 1. A proposed interpretation is that the charge density of the hydroxyl group is decreased by the electron-withdrawing effect of acetylation, which blocks the retro-Michael reaction. This result is consistent with the mechanism of the retro-Michael reaction.
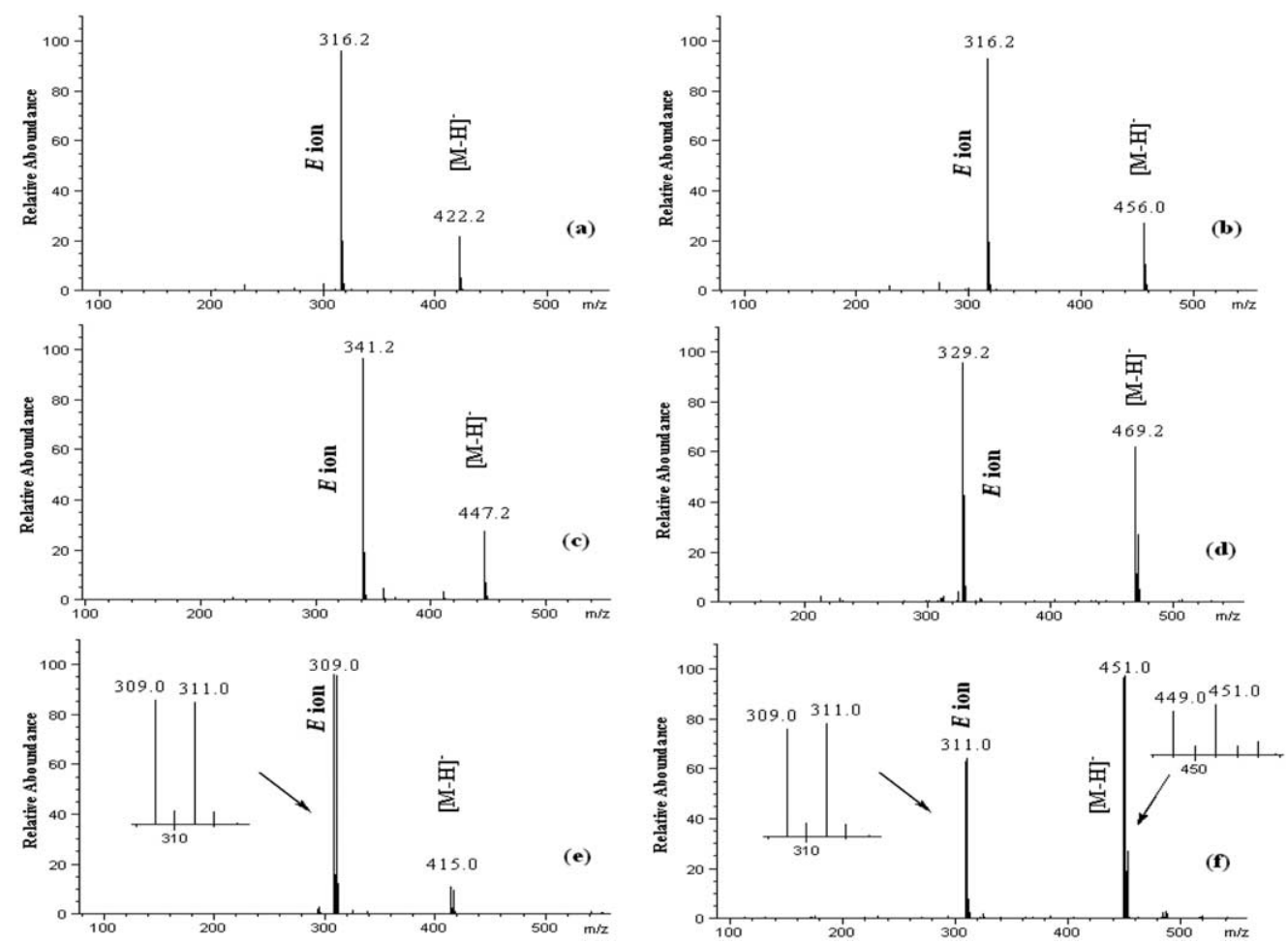

Figure 9. The negative ion ESI in-source CID mass spectra of deprotonated 1 to 6 : (a) deprotonated 1 at $\mathrm{m} / \mathrm{z}$ 422; (b) deprotonated 2 at $\mathrm{m} / \mathrm{z} 456$; (c) deprotonated 3 at $\mathrm{m} / \mathrm{z} 447$; (d) deprotonated 4 at $\mathrm{m} / \mathrm{z} 469$; (e) deprotonated 5 at $\mathrm{m} / \mathrm{z} 415$; (f) deprotonated 6 at $\mathrm{m} / \mathrm{z} 469$. 
<smiles>[X]c1ccc(N(CCc2c([R])cccc2[R])c2nc(OC)cc(OC)n2)cc1</smiles><smiles>[R7]c1cccc2c1CO2</smiles><smiles>[R2]c1ccc([N-]c2nc(OC)cc(OC)n2)cc1</smiles><smiles>[R]c1ccc(N(CCCC2C([R])CC=CC2(Cl)Cl)c2nc(OC)cc(OC)n2)cc1</smiles><smiles>[R7]C1=CC=C(C(C)(C)C)C(=O)C1=O</smiles><smiles>[R]c1ccc(Nc2nc(OC)cc(OC)n2)cc1</smiles>

Scheme 7. Two mechanisms are proposed to explain the formation of $E$ ions observed from negative ion ESI in-source CID of deprotonated 1 to 6 . Path $C$ is proposed to be a gas-phase intramolecular $S_{N} 2$ reaction mechanism. Path $D$ is proposed to be a gas-phase retro-Michael reaction mechanism.

To further explore the process, the MS/MS spectrum of deuterated acetylated 1 at $\mathrm{m} / \mathrm{z} 467$ was obtained by

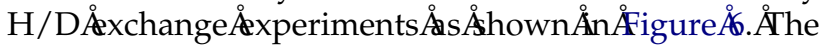
two product ions at $\mathrm{m} / \mathrm{z} 406$ and $\mathrm{m} / \mathrm{z} 407$ in the MS/MS spectrum of deuterated acetylated 1 show that the ion at $\mathrm{m} / \mathrm{z} 407$ is formed when $\mathrm{H}$ of propanol comes from the ortho-position of benzene, and the ion at $\mathrm{m} / \mathrm{z} 406$ is formed when $\mathrm{D}$ is located at the oxygen of the ester. The proposed fragmentation pathway of protonated acetylated $\mathbf{1}$ is shown in Scheme 4.

\section{Explanation of Different Fragmentation Pathways for F Ions from Protonated $\mathbf{1}$ and $\mathbf{3}$ by the Mobile Proton Model}

The fragmentation patterns for protonated Compounds 1 and 3 are determined by multi-stage IRMPD. The IRMPD mass spectrum of the $F$ ion at $\mathrm{m} / \mathrm{z} 318$ from protonated 1 shows the product ions at $\mathrm{m} / \mathrm{z} 276$ and 232,

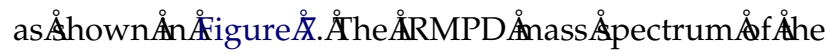
$F$ ion at $\mathrm{m} / \mathrm{z} 343$ from protonated 3 shows only the

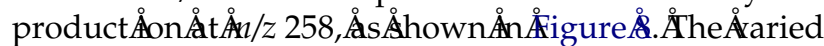
fragmentation pathways are attributed to the varied proton affinities of the amide and ester groups. The migration of the mobile proton to other basic sites can occur in CID processes according to the mobile proton

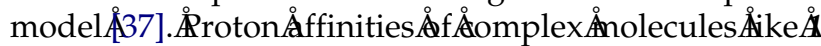
and 3 are not known. However, the gas-phase proton affinity (PA) of a site can be estimated from the gas-

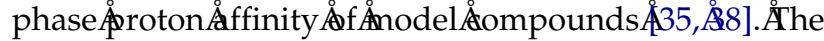
proton affinity of pyrimidinylamine should be similar to or perhaps slightly larger than that of aniline at 921 $\mathrm{kJ} / \mathrm{mol} \AA 38]$.

The proposed fragmentation patterns of the $F$ ion at $\mathrm{m} / \mathrm{z} 343$ are shown in Scheme 5 . The proton affinity of the ester moiety is estimated from acid methyl ester at $821 \mathrm{AJ} / \mathrm{mol}$ [38], Åo Åhe original protonation site of the $F$ ion at $m / z 318$. The ion at $m / z 276$ is generated by loss of neutral propene from the ion at $\mathrm{m} / \mathrm{z} 318$ by charge remote decomposition, and the ion at $\mathrm{m} / \mathrm{z} 232$ is formed by further loss of $\mathrm{CO}_{2}$ from the ion at $m / z 276$.

The proposed fragmentation patterns of the $F$ ion at $\mathrm{m} / \mathrm{z} 343$ are shown in Scheme 6 . The proton affinity of piperidinylamide should be similar to $\mathrm{N}, \mathrm{N}$-dimethyl

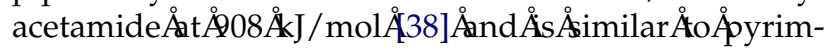
idinylamine. Thus, the proton can transfer from the pyrimidinylamine to amide during the CID process. The protonation of the piperidine amide moiety gives rise to the ion at $\mathrm{m} / \mathrm{z} 258$ by loss of neutral piperidine.

\section{Negative Ion ESI In-Source CID of Deprotonated 1 to 6}

Compounds 1 to 6 have phenol hydroxyl groups; therefore, the fragmentation reactions of deprotonated 1 to 6 were also analyzed via ESI in negative ion mode. The negative ion ESI in-source CID mass spectra of deprotonated 1 to 6 obtained using an

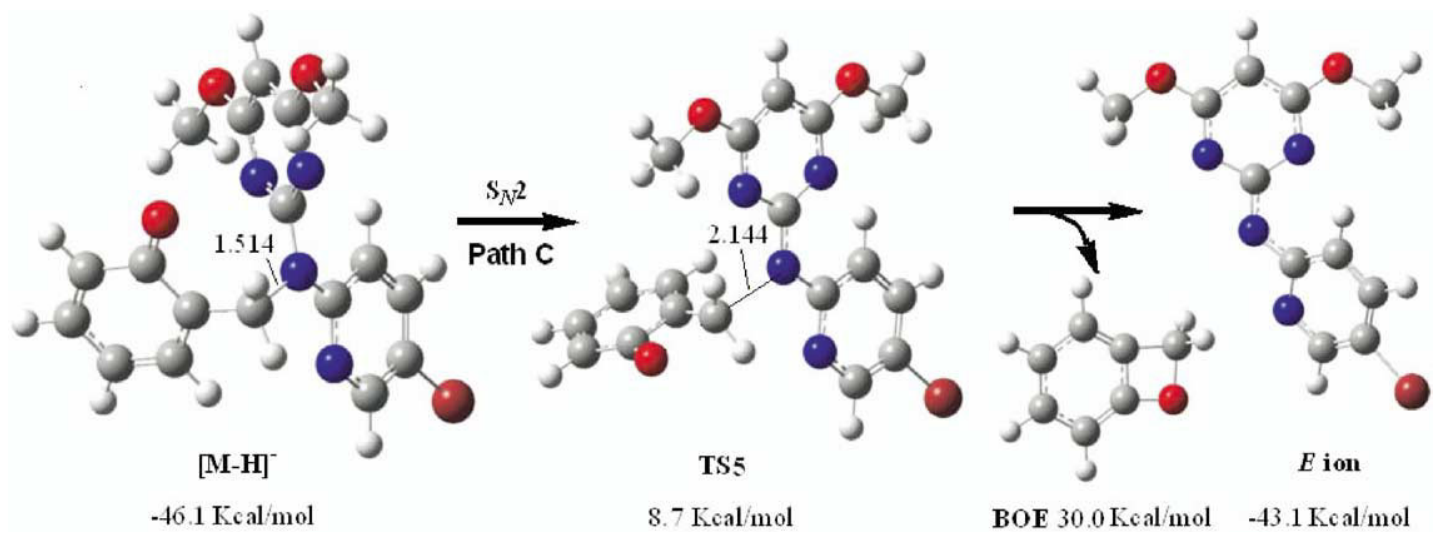

Figure 10. PM3 optimized structures of the species along the $\mathrm{S}_{N} 2$ reaction path of $[5-\mathrm{H}]^{-}$via transition-state (TS5). Heats of formation are given in $\mathrm{kcal} / \mathrm{mol}$ and the lengths of the chemical bonds are given in $\AA$. 


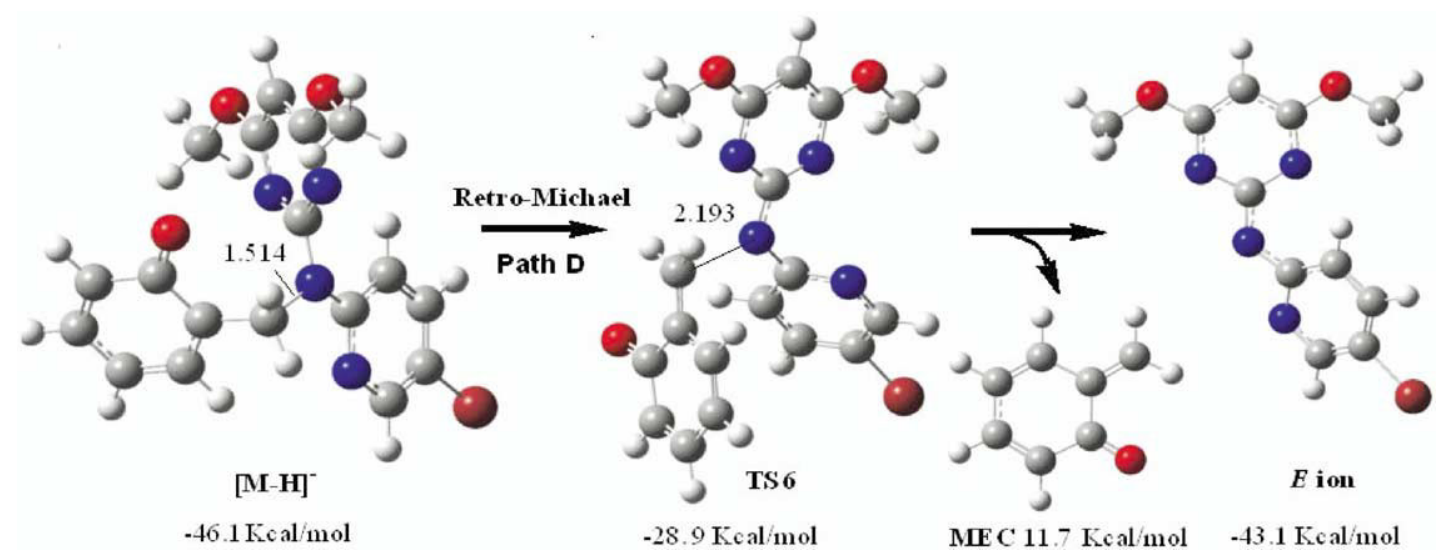

Figure 11. PM3 optimized structures of the species along the retro-Michael reaction path of $[5-\mathrm{H}]^{-}$ via $\mathrm{t}$ transition-state (TS6). Heats of formation are given in $\mathrm{kcal} / \mathrm{mol}$ and the lengths of the chemical bonds are given in $\AA$.

Agilent quadrupole mass spectrometer are depicted

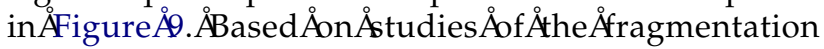
pathways of protonated 1 to 6 , two similar mechanisms are proposed to explain the formation pathway of $E$ ions. The structures of the $E$ ions and the two mechanisms in negative ion ESI in-source CID of the deprotonated compounds are proposed and shown in Scheme 7. Thus, theoretical calculations are also invoked to reveal which model is more reasonable to explain the formation of $F$ ions.

\section{Modeling the Formation Process of E Ions}

Path $C$ is proposed to be a gas-phase intramolecular $S_{N} 2$ reaction mechanism. Path $\mathbf{D}$ is proposed to be a gasphase retro-Michael reaction mechanism. Deprotonated 5 is selected as a model to illustrate this process. The structures of the key species on the potential energy surface of deprotonated 5 were optimized by the semiempirical PM3 method.

In Path $\mathrm{C}$, the phenoxide anion attacks the benzyl carbon inducing the cleavage of the $\mathrm{C}-\mathrm{N}$ bond and the formation of the $E$ ion at $\mathrm{m} / \mathrm{z} 309$ (an aromatic nitrogen anion) and the $2 \mathrm{H}-$ benzo[b]oxete (BOE) through transition-state 5 (TS5). The structure of TS5 was fully optimized by semiempirical PM3 without imposing any constraints. The semiempirical PM3 optimized structures, the lengths of important chemical bonds (in $\AA$ ), and the calculated heats of formation of species involved in the anion type intramolecular $S_{N} 2$ reaction are reported Ån Figure 10 .

Path $\mathbf{D}$ is a gas-phase retro-Michael mechanism, which means a "retro process of a Michael addition reaction." In this process, the electron rearrangement of phenoxide anion induces the cleavage of the $\mathrm{C}-\mathrm{N}$ bond directly and the formation of the $E$ ion at $\mathrm{m} / \mathrm{z} 309$ and 6-methylenecyclohexa-2,4-dienone (MCE) through transition-state 6 (TS6). MCE contains an $\alpha-\beta$ unsaturated ketone moiety in the molecule; the retro cleavage process is a typical Michael addition reaction. The struc- ture TS6 was fully optimized by semiempirical PM3 without imposing any constraints. The semiempirical PM3 optimized structures, the lengths of important chemical bonds (in $\AA$ ), and the calculated heats of formation of species involved in the anion type retroMichael reaction reÅeported Ån FigureÅ1.

A schematic potential energy surface for the two

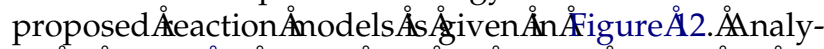

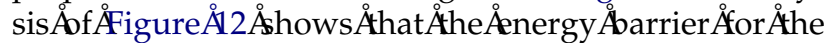
retro-Michael path via TS6 $(17.2 \mathrm{kcal} / \mathrm{mol})$ is much lower than that for the $S_{N} 2$ path via TS5. Moreover, the heat of formation of MCE $(11.7 \mathrm{kcal} / \mathrm{mol})$ is lower that that of $\mathrm{BOE}(30.0 \mathrm{kcal} / \mathrm{mol})$, which causes the product energy of the retro-Michael reaction to be much lower than the product energy of the $S_{N} 2$ reaction. These results indicate that the retro-Michael reaction is more

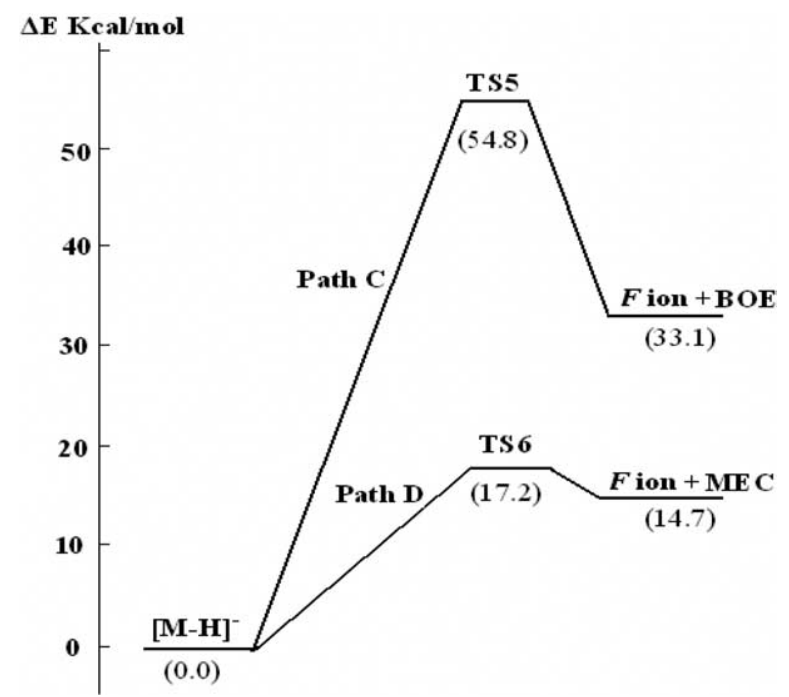

Figure 12. Schematic potential energy surface (relative energies are given in $\mathrm{kcal} / \mathrm{mol}$ ) for the two proposed fragmentation pathway of $[5-\mathrm{H}]^{-}$, calculated by semiempirical PM3. Path $\mathrm{C}$ is an intramolecular $S_{N} 2$ reaction channel via TS5; path D is a retro-Michael reaction channel via TS6. 
reasonable to explain the formation of $E$ ions than the $\mathrm{S}_{\mathrm{N}} 2$ reaction.

Negative ions are important in condensed-phase organic reactions, and the corresponding gas-phase reactions Åre equally fascinating ing that the $E$ ions are nitrogen anions, which are rarely formed in MS/MS processes. The conjugation effects of two adjacent aromatic rings (pyrimidine and benzene) may play an important role in stabilizing the $E$ ions by delocalizing the negative charge of the nitrogen within the aromatic system. Therefore, the $E$ ion can act as a leaving group in this retro-Michael reaction. The gasphase chemistry that occurs in fragmentation/rearrangement processes of the ions helps us to understand

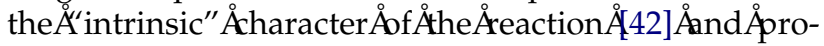
vides clues for potential reaction trends in the con-

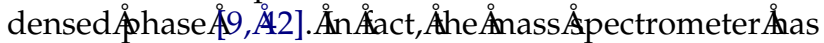
been termed a "complete chemical laboratory" by Beynon $\AA 3$ ]

\section{Conclusions}

According to experimental and theoretical results, the retro-Michael reaction of protonated or deprotonated 2-hydroxybenzyl- $N$-pyrimidinylamine derivatives can now be rationalized. Knowledge of fragmentation mechanisms for product ion mass spectra of $[\mathrm{M}+\mathrm{H}]^{+}$ and $[\mathrm{M}-\mathrm{H}]^{-}$ions for these compounds can aid in the characterization of the related compounds.

\section{Acknowledgments}

The authors thank the National Natural Science Foundation of China (no. 20475059), major state basic research development program (no. 2003CB114406), and the Chinese Academy of Sciences (KGCX2-SW-213-04) for financial support.

\section{References}

1. McLuckey, S. A.; Glish, G. L.; Busch, K. L. Mass Spectrometry/ Mass Spectrometry: Techniques and Applications of Tandem Mass Spectrometry; VCH Publishers: New York, 1988; pp 173-277.

2. De Hoffmann, E.; Stroobant, V. Mass Spectrometry, 2nd ed.; John Wiley and Sons: Chichester, UK, 2001; pp 123-131.

3. Papayannopoulos, I. A. The Interpretation of Collision-Induced Dissociation Tandem Mass Spectra of Peptides. Mass Spectrom. Rev. 1995, 14, 49-73.

4. Vachet, R. W.; Ray, K. L.; Glish, G. L. Origin of Product Ions in the MS/MS Spectra of Peptides in a Quadrupole Ion Trap. J. Am. Soc. Mass Spectrom. 1998, 9, 341-344.

5. Hunt, D. F.; Yates, J. R.; Shabanowitz, J.; Winston, S.; Hauer, C. H. Protein Sequencing by Tandem Mass Spectrometry. Proc. Natl. Acad. Sci. U.S.A. 1986, 83, 6233-6237.

6. Santos, L. S.; Pavam, C. H.; Almeida, W. P.; Coelho, F.; Eberlin, M. N. Probing the Mechanism of the Baylis-Hillman Reaction by Electrospray Ionization Mass and Tandem Mass Spectrometry. Angew. Chem. Int. Ed. 2004, 43, 4330-4333.

7. Sabino, A. A.; Machado, A. H. L.; Correia, C. R. D.; Eberlin, M. N. Probing the Mechanism of the Heck Reaction with Arene Diazonium Salts by Electrospray Mass and Tandem Mass Spectrometry. Angew. Chem. Int. Ed. 2004, 43, 2514-2518
8. Markert, C.; Pfaltz, A. Screening of Chiral Catalysts and Catalyst Mixture by Mass Spectrometric Monitoring of Catalytic Intermediates. Angew. Chem. Int. Ed. 2004, 43, 2498-2500.

9. Eichinger, P. C. H.; Dua, S.; Bowie, J. H. A Comparison of Skeletal Rearrangement Reactions of Even-Electron Anions in Solution and in the Gas Phase. Int. J. Mass Spectrom. Ion Processes 1994, 133, 1-12.

10. Eichinger, P. C. H.; Bowie, J. H. The Gas-Phase Smiles Rearrangement. The Effect of Ring Substitution. An Oxygen-18 Labeling Study. Org. Mass Spectrom. 1992, 27, 995-999.

11. Eichinger, P. C. H.; Bowie, J. H.; Hayes, R. H. The Gas-Phase Smiles Rearrangement: A Heavy Atom Labeling Study. J. Am. Chem. Soc. 1989, 111, 4224-4227.

12. Gronert, S. Mass Spectrometric Studies of Organic Ion/Molecule Reactions. Chem. Rev. 2001, 101, 329-360.

13. Gronert, S. Gas Phase Studies of the Competition Between Substitution and Elimination Reactions. Acc. Chem. Res. 2003, $36,848-857$.

14. Wang, H. Y.; Guo, Y. L.; Lu, L. Studies of Rearrangement Reactions of Protonated and Lithium Cationized 2-Pyrimidinyloxy-N-Arylbenzylamine Derivatives by MALDI-FT-ICR Mass Spectrometry. J. Am. Soc. Mass Spectrom. 2004, 15, 1820 1832.

15. PC Spartan Pro, version 1,0,7; Wavefunction Inc.: Irvine, CA, June 14, 2001.

16. Stewart, J. J. P.; Davis, L. P.; Burggraf, L. W. Semiempirical Calculations of Molecular Trajectories: Method and Applications to Some Simple Molecular Systems. J. Comput. Chem. 1987, 8, 1117-1123.

17. Stewart, J. J. P. Optimization of Parameters for Semiempirical Methods. I. Method. J. Comput. Chem. 1989, 10, 209-220.

18. Stewart, J. J. P. Optimization of Parameters for Semiempirical Methods. II. Applications. J. Comput. Chem. 1989, 10, 221-264.

19. Coolidge, M. B.; Marlin, J. E.; Stewart, J. J. P. Calculations of Molecular Vibrational Frequencies Using Semiempirical Methods. J. Comput. Chem. 1991, 12, 948-952.

20. Little, D. P.; Speir, J. P.; Senko, M. W.; O'Connor, P. B.; McLafferty, F. W. Infrared Multiphoton Dissociation of Large Multiply Charged Ions for Biomolecule Sequencing. Anal. Chem. 1994, 66, 2809-2815.

21. Little, D. P.; McLafferty, F. W. Sequencing 50-Mer DNAs Using Electrospray Tandem Mass Spectrometry and Complementary Fragmentation Methods. J. Am. Chem. Soc. 1995, 117, 6783-6784.

22. Crowe, M. C.; Brodbelt, J. S.; Goolsby, B. J.; Hergenrother, P. Characterization of Erythromycin Analogs by Collisional Activated Dissociation and Infrared Multiphoton Dissociation in a Quadrupole Ion Trap. J. Am. Soc. Mass Spectrom. 2002, 13, 630-649.

23. O'Hair, R. A.; Reid, G. E.; Neighboring Group Versus CisElimination Mechanisms for Side Chain Loss from Protonated Methionine, Methionine Sulfoxide and Their Peptides. Eur. Mass Spectrom. 1999, 5, 325-334.

24. Reid, G. E.; Simpson, R. J.; O'Hair, R. A. J. Leaving Group and Gas Phase Neighboring Group Effects in the Side Chain Losses from Protonated Serine and Its Derivatives. J. Am. Soc. Mass Spectrom. 2000, 11, 1047-1060.

25. Reid, G. E.; Simpson, R. J.; O’Hair, R. A. J. A Mass Spectrometric and ab Initio Study of the Pathways for Dehydration of Simple Glycine and Cysteine-Containing Peptide $[\mathrm{M}+\mathrm{H}]^{+}$ Ions. J. Am. Soc. Mass Spectrom. 1998, 9, 945-956.

26. O'Hair, R. A. J.; Styles, M. L.; Reid, G. E. Role of the Sulfhydryl Group on the Gas Phase Fragmentation Reactions of Protonated Cysteine and Cysteine Containing Peptides. J. Am. Soc. Mass Spectrom. 1998, 9, 1275-1284. 
27. Aggarwal, V. K.; Harvey, J. N.; Richardson, J. Unraveling the Mechanism of Epoxide Formation from Sulfur Ylides and Aldehydes. J. Am. Chem. Soc. 2002, 124, 5747-5756.

28. Tolic, L. P.; Anderson G. A.; Smith, R. D.; Brothers, H. M., II; Spindler, R.; Tomalia, D. A.; Electrospray Ionization Fourier Transform Ion Cyclotron Resonance Mass Spectrometric Characterization of High Molecular Mass Starburst Dendrimers. Int. J Mass Spectrom. Ion Processes 1997, 165/166, 405-418.

29. Peterson, J.; Allikmaa, V.; Subbi, J.; Pehk, T.; Lopp, M.; Structural Deviations in Poly(amidoamine) Dendrimers: A MALDI-TOF MS Analysis. Eur. Polym. J. 2003, 39, 33-42.

30. He, M.; McLuckey, S. A. Tandem Mass Spectrometry of Half-Generation PAMAM Dendrimer Anions. Rapid Commun. Mass Spectrom. 2004, 18, 960-972.

31. Shen, L.; Sha, Y. W.; Hong, X. Y. Tandem Mass Spectrometric Analysis of Distinct Fragmentation Patterns to $[\mathrm{M}+\mathrm{Na}] / \mathrm{Z}$ and $[\mathrm{M}+\mathrm{H}] / \mathrm{Z}$ of Dendritic $\mathrm{Al}$ (III) and Zn (II) Quinolates. Rapid Commun. Mass Spectrom. 2004, 18, 1534-1538.

32. Longevialle, P. Ion-Neutral Complexes in the Unimolecular Reactivity of Organic Cations in the Gas Phase. Mass Spectom. Rev. 1992, 11, 157-192.

33. Tu, Y. P.; Harrison, A. G. Fragmentation of Protonated Amides Through Intermediate Ion-Neutral Complexes: Neighboring Group Participation. J. Am. Soc. Mass Spectrom. 1998, 9, 454-462.

34. Harrison, A. G.; Young, A. B. Fragmentation of Protonated Oligoalanines: Amide Bond Cleavage and Beyond. J. Am. Soc. Mass Spectrom. 2004, 15, 1810-1819.

35. Sonsmann, G; Römer, A.; Schomburg, D. Investigation of the Influence of Charge Derivatization on the Fragmentation of Multiply Protonated Peptides. J. Am. Soc. Mass Spectrom. 2002, 13, 47-58.
36. Kamel, A. M.; Fouda, H. G.; Brown, P. R.; Munson, B. J. Mass Spectral Characterization of Tetracyclines by Electrospray Ionization, H/D Exchange, and Multiple Stage Mass Spectrometry. J. Am. Soc. Mass Spectrom. 2002, 13, 543-557.

37. Dongré, A. R.; Jones, J. L.; Somogyi, A.; Wysocki, V. H. Influence of Peptide Composition, Gas-Phase Basicity, and Chemical Modification on Fragmentation Efficiency: Evidence for the Mobile Proton Model. J. Am. Chem. Soc. 1996, 118, 8365-8374.

38. (a) De Hoffmann, E.; Stroobant, V. Gas Phase Ion Thermochemical Data of Molecule. In Mass Spectrometry, 2nd ed. John Wiley \& Sons, Ltd.: Chichester, UK. 2001, pp 389-391; (b) Mallard, W. G.; Linstrom, P. J. NIST Chemistry WebBook, NIST Standard Reference Database Number 69, National Institute of Standards and Technology: Gaithersburg, MD, 1998,Ånttp://webbok.nist.gov.

39. Bowie, J. H. The Fragemenation of Even-Electron Organic Negative Ion. Mass Spectrom. Rev. 1990, 9, 349-379.

40. Bowie, J. H. Twenty-Five Years of Negative Ion Studies at Adelaide. Org. Mass Spectrom. 1993, 28, 1407-1413.

41. Reeks, L. B.; Eichinger, P. C. H.; Bowie, J. H. Ortho Rearrangements of O-Alkylphenoxide Anions. Rapid Commun. Mass Spectrom. 1993, 7, 286-287.

42. Mcluckey, S. A.; Glish, G. L.; Busch, K. L. Mass Spectrometry/ Mass Spectrometry: Techniques and Applications of Tandem Mass Spectrometry; VCH Publishers: New York, 1988; pp 123-131

43. Porter, C. J.; Beynon, J. H.; Ast, T. The Modern Mass Spectrometer-A Complete Chemical Laboratory. Org. Mass Spectrom. 1981, 16, 101-114. 